\title{
META-ANALYSIS: ASSOCIATION BETWEEN SOCIAL SUPPORT AND THE ADHERENCE TO ANTIRETROVIRAL THERAPY IN ADULTS PATIENTS WITH HIV/AIDS
}

\author{
Musta'inul Habibi'), Setyo Sri Rahardjo²), Bhisma Murti') \\ 1)Masters Program in Public Health, Universitas Sebelas Maret \\ ${ }^{2)}$ Faculty of Medicine, Universitas Sebelas Maret
}

\begin{abstract}
Background: HIV/AIDS is a international health issue due to its high incidence. HIV infection is strongly marked by stigma, prejudice and rejection by society, which can lead to social and family isolation, and consequent undermining of social networks and health monitoring. The absence of social support has been associated with negative effects on psychological and physical well-being in people lovong with HIV/AIDS, such as depression, lower self-esteem, inadherent to therapy or medical treatment, and progression to the final stage of the disease. This study aimed to investigate the association between social support and the adherence to antiretroviral therapy in adults with HIV/AIDS.
\end{abstract}

Subjects and Method: This was a systematic review and meta-analysis was conducted by PRISMA flow diagram. The articles were collected from Google Scholar, PubMed, Springer Link, Clinical key, and ProQuest databases. Keywords used "Social Support or family support and adherence antiretroviral". The inclusion criteria were full text, articles were published from year 2020 to 2021, cross-sectional studies, used English language, and reported adjusted Odds Ratio. Articles that met the criteria were analyzed by Revman 5.3 .

Results: A meta-analysis from 9 observational study reported that strong social support increased adherence to antiretroviral therapy 1.4 times than patients with low social support $(\mathrm{aOR}=1.46 ; 95 \% \mathrm{CI}=1.08$ to $1.97 ; \mathrm{p}=0.010)$.

Conclusion: Strong social support increases adherence to antiretroviral therapy 1.4 times than patients with low social support.

Keywords: adherence, antiretroviral therapy, HIV/AIDS, social support

\section{Correspondence:}

Musta'inul Habibi. Masters Program in Public Health, Universitas Sebelas Maret. Jl .Ir. Sutami 36A, Surakarta 57126, Central Java. Email: Mustainul87@gmail.com. Mobile: o85649959811 